\title{
WISHFUL THINKING VERSUS REALITY: HIGH-GROWTH ASPIRATIONS OF START-UPS AND ESTABLISHED ENTREPRENEURS IN ASEAN
}

\author{
Ulrike Guelich \\ Bangkok University School of Entrepreneurship and Management (BUSEM), \\ 119 Rama 4 Rd., Klongtoei, Bangkok 10110, Thailand \\ E-mail: ulrike.guelich@gmail.com
}

Published online: 30 June 2020

To cite this article: Guelich, U. (2020). Wishful thinking versus reality: High-growth aspirations of start-ups and established entrepreneurs in ASEAN. Asian Academy of Management Journal, 25(1), 147-166. https://doi.org/10.21315/aamj2020.25.1.8

To link to this article: https://doi.org/10.21315/aamj2020.25.1.8

\begin{abstract}
Most enterprises in the Association of Southeast Asian Nations (ASEAN) are micro and small enterprises. Few have aspirations to "dream big." From an economic perspective, high-growth firms provide many benefits. This empirical study explores both country-level contextual factors such as country competitiveness or innovativeness and individual-level factors associated with high-growth, such as an entrepreneur's market expansion plans, new product perceptions, export orientation and use of latest technologies. In this context, we investigate whether to "dream big" is associated with specific strategic intentions and which influencing factors hinder or foster aspirations to grow the business by more than 20 employees within five years while developing it into an established business. Utilising random sampling of data in six ASEAN countries, collected in the years 2013 to 2015 and comparing male to female entrepreneurs, the regression results of this empirical study show that although high growth-oriented entrepreneurs in both start-ups and established enterprises account for only $2.7 \%$ of all enterprises in this study, high-growth aspirations can only partially be sustained by early-stage entrepreneurs into the next business phase since it depends on several factors: (1) receiving funding (for both genders); (2) being export oriented (for male entrepreneurs); and (3) perceptions of having new products or services to offer to the market (for women entrepreneurs). Both genders are less prone to pursue their initial early-stage growth goals as established entrepreneurs. We infer that established entrepreneurs gain more clarity on the deployment of growth through
\end{abstract}

(C) Asian Academy of Management and Penerbit Universiti Sains Malaysia, 2020. This work is licensed under the terms of the Creative Commons Attribution (CC BY) (http://creativecommons. org/licenses/by/4.0/). 
implementation in the organisation while running their businesses and therefore may be more realistic in their predictions or less confident in their pursuit of ambitious goals.

Keywords: high-growth venture, growth aspirations, entrepreneurship, ASEAN, exportorientation

\section{INTRODUCTION}

Interest in firm growth and its influencing factors are important to academics and policymakers, but not necessarily to the entrepreneur, who may decide to sustain the business without growth. From an economic point of view, firm growth contributes to socio-economic development through job creation and tax revenue (Douglas, 2013). High-growth entrepreneurship in particular also has a strong positive impact on sustainable economic growth and overall economic development (Capelleras et al., 2016; Haltiwanger et al., 2013). In most countries, fewer women than men are starting ventures, independent of growth aspirations. The gender gap ratios have positively decreased during the last few years, especially in factor- and efficiency-driven Asia, Latin America and the Caribbean and in innovation-driven European countries (Kelley et al., 2015). Analysis of high-growth aspirations from a gender perspective is specifically relevant for the Association of Southeast Asian Nations (ASEAN) region, since five of the six ASEAN countries in this study have the unique feature of a female to male ratio of at least 1:1 in start-ups and early-stage businesses. Previous literature suggests that women's firms tend to be smaller and grow more slowly due to constraints in access to resources such as finance or human capital, thus limiting their growth options (Brush et al., 2004). To understand high-growth and differences between male and female entrepreneurs is important for policymakers since they focus on economic impact and inclusive impact, respectively (Terjesen et al., 2016).

The purpose of this empirical study is to explore whether existing high-growth aspirations can be maintained once early-stage entrepreneurs enter the established business phase and whether there are gender-related differences. To understand the mechanisms driving aspirations of entrepreneurs will help policy makers to create targeted and more effective policies to promote an entrepreneurial society and support a sustainable entrepreneurship ecosystem. In this context, we attempt to identify influencing factors that hinder or foster the entrepreneurial goal to grow by more than 20 employees within five years. In this way, we can also identify the mechanisms driving high-growth aspirations from a start-up to an established business phase. This study investigates whether to "dream big" is associated with factors such as specific strategic intentions and their alignment, the availability of financial resources, an entrepreneurial mind-set with export orientation, 
innovativeness in products and services and the use of latest technology in business. In addition, we explore how country-level performance in innovativeness differs from an entrepreneur's individual-level orientation towards high-growth aspirations.

\section{LITERATURE REVIEW}

Many stories and media reports about extraordinarily successful entrepreneurs shape common beliefs in the public and paint a certain image of a high-growth entrepreneur. However, the factors that drive high-growth and which country-level variables enable an ecosystem relevant for entrepreneurs in all business phases are widely unknown. To explore this question, we investigate factors associated with firm growth as well as an individual entrepreneur's characteristics and related indicators, such as: (1) an entrepreneur's market expansion plans; (2) perceptions of innovativeness of products and services by making new products available for customers and having no competitors; (3) perceptions of export orientation; and (4) the use of latest technology in the business. In addition, the influence of contextual factors, such as unique country competitiveness or innovativeness, are explored to investigate their importance as base conditions in an entrepreneurial ecosystem for high-growth enterprises.

Most policymakers recognise the financial constraints of small or medium-sized firms operating in a variety of industries and locations. As a result, policies often try to target a wide range of entrepreneurs. However, these policies often fail to recognise that benefits for entrepreneurs can vary dramatically, depending on the entrepreneur's own aspirations, such as the desire to build a high-growth business (Henderson, 2002).

\section{High-growth Aspirations}

From an economic perspective, high-growth firms provide many benefits. Previous research has shown that even though they only make up a small portion of all entrepreneurial activity, high-growth firms contribute more than others to economic growth (Davidsson et al., 2006; Minniti, 2013; Terjesen et al., 2016, Wong et al., 2005). Besides job creation in significant numbers and both personal and corporate tax generation, high-growth firms usually focus on commercialising innovative products, services, and processes (Haltiwanger et al., 2013). It is self-evident that economic stakeholders from macro- to micro-level and from national to community-level, concentrate on the encouragement of and support for start-ups and established companies with significant growth potential. Firms 
grow in different ways and their patterns can vary significantly - also over timefor different reasons (Delmar et al., 2003; Shepherd \& Wiklund, 2009) and this heterogeneity of high-growth firms provides a challenge for policy makers (Mason \& Brown, 2013).

On the other hand, it is also a well-researched fact that over $70 \%$ of all women entrepreneurs, specifically also in the ASEAN region, tend to have no employees besides themselves (Xavier et al., 2015) and that the majority of growth-oriented firms have been started by men, not by women (Robb et al., 2014). In addition, only one out of ten firms growing to at least 15 employees in developing countries was found to be female owned (Nichter \& Goldmark, 2009). All entrepreneurs in the region, regardless of gender, experience internal constraining factors such as low levels of entrepreneurial skills and external factors such as restricted access to finance, lack of market information, and the prevalence of general administrative procedures and regulations (Chen, 2001; Xavier et al., 2015) which limits their business growth capabilities.

Research findings tend to encourage policymakers to focus on high-growth entrepreneurship rather than on new venture creation and self-employment in general (Terjesen et al., 2016). Scant research exists that focuses on a firm's growth depending on its business phase, in addition to its size and its business sector (Delmar et al., 2003; Geroski, 2002; Penrose, 2009). A study on high-growth firms in Scotland found that established firms create more jobs than start-up high-growth firms. High-growth technology firms tend to be in the market typically for longer than ten years (Mason \& Brown, 2013). A literature gap exists regarding changes of these high-growth aspirations as a function of business phase, be it as a start-up with a young entrepreneur or as a more established entrepreneur.

Recent studies on the entrepreneurial ecosystem point out that its framework conditions are influenced by various factors, where each single condition can either foster or hinder entrepreneurship, with finance, government policies, government programs, and market openness being examples of influencing components (Isenberg, 2010; Mason \& Brown, 2014). Key issues include educational background, personal aspirations and motivations, training and skill development, external networking, desire to succeed, and fear of failure (Dumas, 2001; Robinson, 2001). The realisation that not all firms will grow offers a powerful insight to adjust traditional government policies regarding entrepreneurship, since governments often presume that all entrepreneurs want to grow and therefore target general firm growth stimulation in their programs. Insights of studies on high growth might help to improve the potential for better development outcomes by using new approaches (Nichter \& Goldmark, 2009). 
The majority of studies on firm growth use increase in employee numbers as a metric, but high growth firms do not all grow in the same way. This implies that researchers should measure different forms of growth with different growth measures. A single measure such as employee growth likely provides information only about this specific form of organisational growth (Delmar et al., 2003). Other scholars, especially when focused on developed countries, tend to measure growth as revenue growth or asset growth. However, employment growth is a rather reliable measure as entrepreneurs can easily answer a question about how many employees they added in the last few years or how many they are going to add in future years. To assess reliable financial data for mostly small firms or start-ups is often difficult (Mead \& Liedholm, 1998; Robson \& Obeng, 2008). In this study, high-growth aspirations of entrepreneurs are defined as the portion of entrepreneurs who intend to grow their businesses by 20 or more employees in the next five years.

\section{Innovativeness, Competitiveness, and Market Expansion}

ASEAN, with its workforce of 400 million and its consumer base of 626 million people has been successful in raising the living standards of its ten member countries and is expected to continuously grow and become the world's fifth biggest economy by 2020 (World Bank, 2014). Both policy makers and academics agree that entrepreneurs and their businesses play a pivotal role in the development and well-being of their societies, whilst external stimulating conditions in the ASEAN Economic Community (AEC) bring particular challenges and opportunities to entrepreneurs in the region. High-growth firms, in particular, are sensitive and easily affected by macro conditions and regulatory issues (Mason \& Brown, 2013).

The AEC took action at the end of 2015 and opened the way to freer transfer of capital, skilled labour, but also free movement of goods, services and investments, thus building a base for enterprises to target market expansion and growth. Following the launch of AEC, the ASEAN Strategic Action Plan for Small and Medium-sized Enterprise Development 2016-2025 aims to realise its vision of globally competitive and innovative SMEs by promoting productivity, technology, and innovation (ASEAN, 2015). Among other targets, this includes increased access to finance, enhanced market access, and internationalisation by enhancing policies and a regulatory environment promoting entrepreneurship.

According to the Global Innovation Index (GII) 2017 by Cornell University, INSEAD and the World Intellectual Property Organization (WIPO), which aims to capture the multi-dimensional facets of innovation, the six member countries of the ASEAN rank between 7th (Singapore) and 87th (Indonesia) out of 127 
economies for innovation (Dutta et al., 2017). Focusing on innovation-driven economic development, GII assesses dozens of metrics, from patent filings to education spending to provide tools and information about innovative activities to decision makers. In the region, Singapore (7th), Malaysia (37th), Vietnam (47th) and Thailand (51st) are above average, whereas the Philippines (73rd) and Indonesia (87th) rank below average.

The Global Competitiveness Report 2015/2016 and its Global Competitiveness Index (GCI) highlight key factors and their interrelations that determine economic growth and a country's level of present and future prosperity. Certain positive developments, such as the rapid dissemination of information and communication technologies (ICTs), change business models and revolutionise industries, and lead to innovation waves that could drive longer-term growth (Schwab et al., 2016).

\section{Access to Finance for Growth}

The availability of financial resources, equity, and debt for new and growing firms, including grants and subsidies, is rated below average in ASEAN, with a tendency to decrease rather than increase (Xavier et al., 2016). For various reasons, lack of funding as a constraining factor for growth is mentioned more often by smaller rather than larger firms (Schiffer \& Weder, 2001). The small and medium-sized companies in developing countries are less likely to apply for formal bank loans, and thus typically rely on funding from family, friends, and informal channels (Bigsten et al., 2003). Microfinance as a further option has less outreach and limits a company's potential for growth (Swinnen, 2005).

For different business phases, high-growth aspirations of established entrepreneurs often require upgrading or there may be a need to exchange existing technology to newer or latest technologies, which entails investments and additional financial constraints. Previous research emphasises credit constraints as a barrier to investment in high-growth and high-return activities (Banerjee \& Munshi, 2004). However, the findings of Hausmann et al. (2007) suggest that even if the functioning of financial markets is improved, this would not necessarily generate much new expansion and more export activities, since funding alone does not enable entrepreneurs to extend their outreach into international activities.

\section{Conceptual Framework and Hypothesis Development}

Based on the literature, the conceptual model illustrated in Figures 1 and 2 was created to guide the empirical research, utilising primary and secondary data. In the models, venture growth, defined as employee growth of 20 or more people 
in the next 5 years, is posited to be a function of the growth aspiration of the entrepreneur. Entrepreneurs are distinguished by business phase as early-stage entrepreneurs with businesses of up to 42 months of existence and established entrepreneurs whose firms have been operating for more than 42 months.

On a country level (Figure 1), growth orientation is a function of financial market development, innovation, business sophistication, and global innovation, with secondary country data stemming from the Global Competitiveness Report 2015/2016 and the Global Innovation Index 2017, with growth aspirations stemming from the primary data source Global Entrepreneurship Monitor (GEM). To test the impact of the country-level influencers, the following hypotheses have been developed:

$\mathrm{H}_{1}$ : GCI Financial Market Development has significant positive impact on growth aspirations

$\mathrm{H}_{2}$ : $\quad$ GCI Innovation has significant positive impact on growth aspirations

$\mathrm{H}_{3}$ : GCI Business Sophistication has significant positive impact on growth aspirations

$\mathrm{H}_{4}$ : GCI GII has significant positive impact on growth aspirations

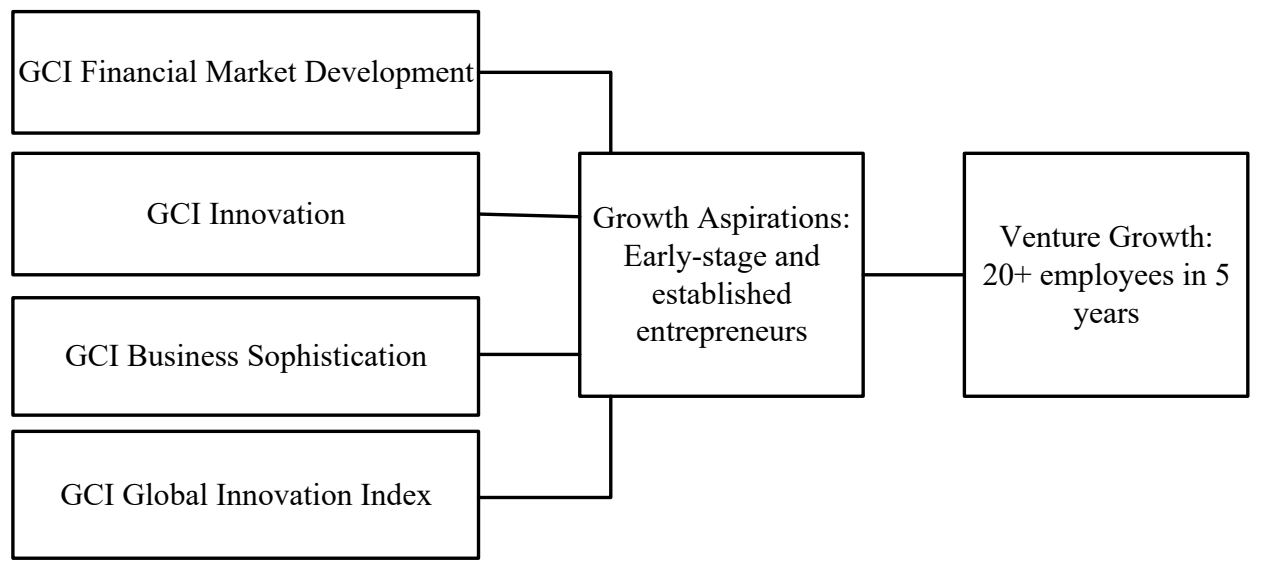

Figure 1. Conceptual model for country-level indicators for high-growth aspirations leading to venture growth

On an individual level (Figure 2), growth orientation is a function of informal funds in the last three years, market expansion plans, new product perception, no competitor perception, export orientation, new technology use, and new product 


\section{Ulrike Guelich}

market combination, stemming from the primary data source GEM. To test the impact of the individual-level influencers, the following hypotheses have been developed:

$\mathrm{H}_{5}$ : Informal funding has significant positive impact on growth aspirations

$\mathrm{H}_{6}$ : Market expansion plans have significant positive impact on growth aspirations

$\mathrm{H}_{7}$ : New product perceptions have significant positive impact on growth aspirations

$\mathrm{H}_{8}$ : No competitor perception has significant positive impact on growth aspirations

$\mathrm{H}_{9}$ : Export orientation has significant positive impact on growth aspirations

$\mathrm{H}_{10}$ : New technology use has significant positive impact on growth aspirations

$\mathrm{H}_{11}$ : New product market combination has significant positive impact on growth aspirations

\section{Informal funds in the last 3 years}

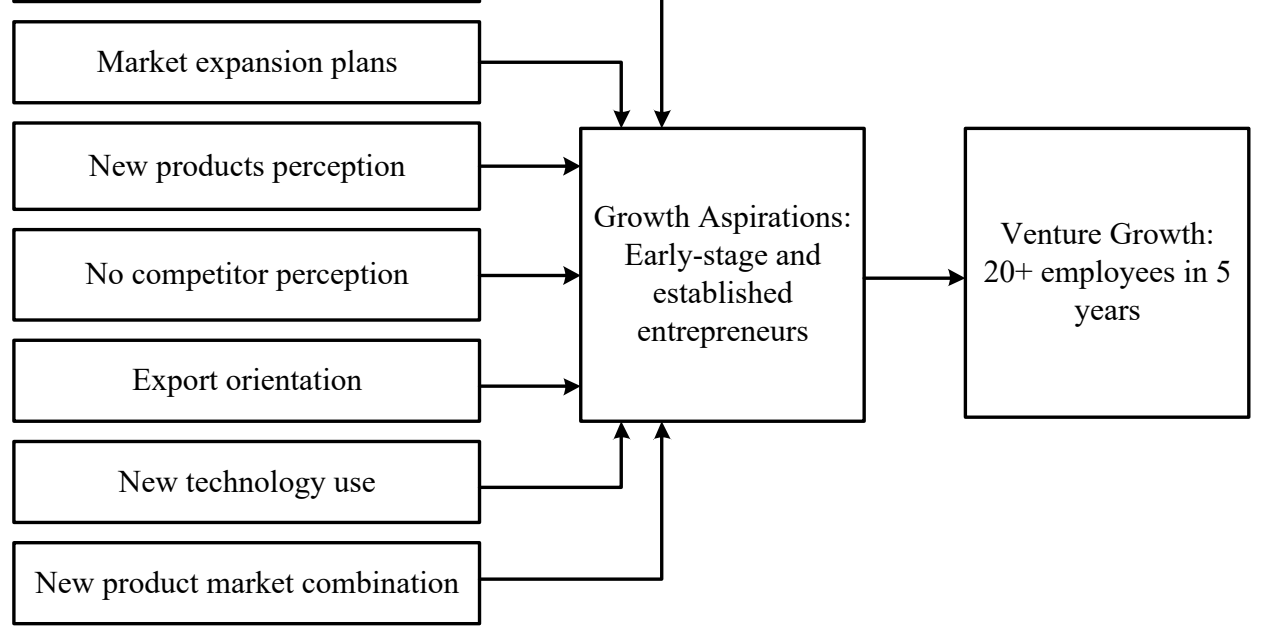

Figure 2. Conceptual model for individual-level indicators for high-growth aspirations leading to venture growth 


\section{RESEARCH METHODOLOGY}

This study uses GEM data of the six ASEAN countries namely Indonesia, Malaysia, Philippines, Singapore, Thailand, and Vietnam, collected in the GEM Adult Population Surveys (APS) 2013, 2014, and 2015 plus secondary data from the Global Competitiveness Report and GII. GEM national teams across the globe collect individual-level data on an annual basis and analyse entrepreneurial activity across countries and the factors that make a country entrepreneurial. Each participating GEM national research team undertakes the APS along with a National Expert Survey (NES). The APS questions, which include the variables used in this study, are answered by a random sample of a minimum of 2,000 adults, and concern their engagement in entrepreneurial activity and their attitudes towards entrepreneurship. The total sample size for the APS of the six ASEAN countries for three consecutive years accounts for 60,187 respondents. The resulting samples of 18,325 entrepreneurs consist of start-ups or young businesses of up to an age of 42 months $(\mathrm{N}=9,306)$ and of established businesses that are older than 42 months $(\mathrm{N}=9,019)$. Each entrepreneur was asked how many people in addition to the owners were currently employed and how many they expect there to be in five years from now.

Linear regression analysis was used to answer the question as to whether innovativeness and competitiveness on a country level predict high-growth aspirations, to identify related hindering or fostering factors, in both total earlystage entrepreneurial activity (TEA) and established businesses and whether existing high-growth aspirations can be maintained once early-stage entrepreneurs enter the established business phase. In the model summary, R-square, as overall measure of the strength of the association, determined the proportion of variance in the dependent variable (high-growth aspirations) which can be predicted from the independent variables (informal funds, market expansion plans, internationalisation, innovativeness of products and services, competitive markets, use of latest technology, and new product market combination). Analysis of variance (ANOVA) was used to predict the dependent or outcome variable with an indication of the statistical significance of the regression model of less than 0.05 .

The two dependent variables in both country-level and individual-level analysis were high-growth aspirations of 20 or more employees within the next five years for both business phases. Independent variables on country-level were indicators from the GCI: Financial market development, innovation, and business sophistication (which includes the assessment of local supplier quantity and quality, state of cluster development, nature of competitive advantage, value chain breadth, 
control of international distribution, production process sophistication, extent of marketing, willingness to delegate authority), and factors from the GII.

Independent variables on an individual-level were: (1) availability of informal funds in the last three years; (2) market expansion plans; (3) internationalisation; (4) innovativeness of products and services; (5) competitive markets; (6) use of latest technology; and (7) new product market combination. Regression analysis is used to answer the question, by identifying which factors influence high-growth aspirations of early-stage and established entrepreneurs and whether there are gender differences.

\section{RESULTS}

High-growth aspiration entrepreneurs accounted for only 487 entrepreneurs out of the total sample of 60,187 respondents which comprised 290 or $1.6 \%$ early-stage (186 male; 104 female) and 197 or $1.1 \%$ established entrepreneurs (114 male; 84 female). The sample size split by gender did not enable us to analyse the data on a single country basis for a cross-country comparison. The regression analysis of high-growth aspirations for early-stage and established entrepreneurs and the country-level determinants of financial market development, innovation and business sophistication, and global innovativeness show clear significance for high-growth aspirations, especially for established businesses (EB) of both genders. For EB, all four independent variables were significant (Table 1) with a strong negative correlation for financial market development, both for male $(-0.989 / 0.001)$ and female established businesses $(-1.114 / 0.000)$. Financial market development in GCI is measured on a scale from 1 (largely non-existent) to 7 (extremely numerous) and the region is assessed as being rather average with a score of 4.55 . Hypothesis $\mathrm{H}_{1}$ states that financial market development has significant positive impact on venture growth is not confirmed; on the contrary, it can be considered as a significantly constraining factor for growth aspirations. Interestingly, financial market development is not significant for both male and female TEA high-growth entrepreneurs. This could be explained by availability of informal funding. Male start-ups received higher informal funding than women, probably easing their way to growth. Only $24 \%$ of the female early-stage entrepreneurs received more than USD5,000 in informal funding versus $45.4 \%$ of their male counterparts. Comparably, this also holds for established entrepreneurs, where $38.5 \%$ of females versus $60.8 \%$ of males received more than USD5,000 in informal funding. 
A similar distinction is found for the business sophistication determinant and the two business phases: it is not significant for TEA high-growth entrepreneurs, but shows a correlation for established businesses, stronger for females $(0.612 / 0.002)$ than for males $(0.344 / 0.019)$, thus confirming hypothesis 3 only for EB. Innovation is significant for both genders in both business phases, although only to minimal extent, confirming hypothesis $\mathrm{H}_{2}$. Hypothesis $\mathrm{H}_{4}$ is only partly confirmed, since the GII positively and minimally impacts established entrepreneurs of both genders and only female TEA entrepreneurs.

Table 1

Regression analysis of country-level indicators for high-growth aspirations

\begin{tabular}{llcccc}
\hline & & \multicolumn{2}{c}{ TEA high growth } & \multicolumn{2}{c}{ EB high growth } \\
\hline Male & Country & B & Sig. & B & Sig. \\
& GCI Financial Market Development & -0.010 & 0.052 & -0.021 & 0.000 \\
& GCI Innovation & 0.067 & 0.013 & 0.128 & 0.000 \\
& GCI Business Sophistication & -0.217 & 0.139 & 0.344 & 0.019 \\
& GII Global Innovation Index & 0.019 & 0.066 & 0.042 & 0.000 \\
Female & Country & -0.009 & 0.006 & -0.013 & 0.059 \\
& GCI Financial Market Development & -0.286 & 0.136 & -1.114 & 0.000 \\
& GCI Innovation & 0.043 & 0.022 & 0.057 & 0.000 \\
& GCI Business Sophistication & 0.015 & 0.877 & 0.612 & 0.002 \\
& GII Global Innovation Index & 0.018 & 0.007 & 0.022 & 0.000 \\
\hline
\end{tabular}

Dependent variables: TEA high-growth 20+ employees and established businesses high-growth 20+ employees

A descriptive analysis of the prevalence of the individual-level indicators shows that established entrepreneurs in general are more reluctant to expand their businesses (TEA: male 57.6\% / female 59.3\%; EB: male 43.2\% / female $41.5 \%$ ), use fewer new technologies, have fewer new products and slightly more competition. With the exception of new technology-use for all businesses and market expansion for TEA, females score lower than their male counterparts. The majority of entrepreneurs do not have more than $25 \%$ of customers residing outside their country of origin. Only $5.4 \%$ of male $/ 3.1 \%$ of female TEA and $3.1 \%$ of male $/ 1.6 \%$ of female established businesses are export oriented.

Regression analysis of high-growth aspirations on the individual-level was significant for both business phases and both genders (Table 2). It was comparably significant at $p=0.000$ for male and female TEA entrepreneurs and for male 


\section{Ulrike Guelich}

established business owners, and slightly less significant at $p=<0.05$ level (0.043) for female established entrepreneurs.

Table 2

Summary results for the regression analysis of individual-level indicators

\begin{tabular}{llccccc}
\hline & & $\begin{array}{c}\text { Sum of } \\
\text { squares }\end{array}$ & df & $\begin{array}{c}\text { Mean } \\
\text { square }\end{array}$ & F & Sig. \\
\hline Male TEA & Regression & 3.567 & 7 & 0.510 & 4.772 & 0.000 \\
& Residual & 34.601 & 324 & 0.107 & & \\
& Total & 38.169 & 331 & & & \\
Female TEA & Regression & 1.647 & 7 & 0.235 & 6.642 & 0.000 \\
& Residual & 9.849 & 278 & 0.035 & & \\
& Total & 11.497 & 285 & & & \\
Male EB & Regression & 2.544 & 7 & 0.363 & 5.872 & 0.000 \\
& Residual & 18.755 & 303 & 0.062 & & \\
& Total & 21.299 & 310 & & & \\
& Regression & 0.765 & 7 & 0.109 & 2.118 & 0.043 \\
& Residual & 11.504 & 223 & 0.052 & & \\
& Total & 12.268 & 230 & & & \\
\hline
\end{tabular}

Dependent variables: TEA high-growth 20+ employees and established businesses high-growth 20+ employees

In Table 3, the regression analysis of high-growth aspirations for early-stage and established enterprises and their determinants reveals correlations for all entrepreneurs of both genders who had received funding in the last 3 years, thus confirming $\mathrm{H}_{5}$. The three hypotheses $\mathrm{H}_{6}$ (market expansion), $\mathrm{H}_{8}$ (no competitor perception), and $\mathrm{H}_{11}$ (new product market combination) are not significant in impacting high-growth aspirations, independent of gender and business phase. $\mathrm{H}_{7}$ (new products perceptions) was only significant for female established businesses and $\mathrm{H}_{9}$ (export orientation) was also partly confirmed with a significant impact on venture growth for both male $(0.157 / 0.013)$ and female $(0.312 / 0.000)$ TEA and for male EB (0.231/0.000). Early-stage male entrepreneurs who utilise new and latest technologies tend to have growth aspirations, only partly confirming hypothesis $\mathrm{H}_{10}$. High-growth expectations of early-stage women entrepreneurs are higher than for their male counterparts, positively influenced only by export orientation and for those who also received informal funds in the last three years. 
Table 3

Regression analysis of individual-level indicators for high-growth aspirations

\begin{tabular}{|c|c|c|c|c|c|}
\hline & & \multicolumn{2}{|c|}{ TEA high growth } & \multicolumn{2}{|c|}{ EB high growth } \\
\hline & & $\mathrm{B}$ & Sig. & $\mathrm{B}$ & Sig. \\
\hline \multirow[t]{8}{*}{ Male } & (Constant) & -0.026 & 0.589 & -0.057 & 0.186 \\
\hline & $\begin{array}{l}\text { Informal funds in the last } 3 \\
\text { years }\end{array}$ & 0.067 & 0.000 & 0.050 & 0.001 \\
\hline & Market expansion & -0.084 & 0.176 & 0.038 & 0.432 \\
\hline & New products perception & 0.039 & 0.412 & 0.000 & 0.998 \\
\hline & No competitor perception & 0.014 & 0.816 & 0.005 & 0.907 \\
\hline & Export orientation & 0.157 & 0.013 & 0.231 & 0.000 \\
\hline & New technology & 0.122 & 0.031 & -0.052 & 0.307 \\
\hline & $\begin{array}{l}\text { New product market } \\
\text { combination }\end{array}$ & -0.026 & 0.752 & -0.018 & 0.775 \\
\hline \multirow[t]{8}{*}{ Female } & (Constant) & -0.025 & 0.431 & -0.025 & 0.517 \\
\hline & $\begin{array}{l}\text { Informal funds in the last } 3 \\
\text { years }\end{array}$ & 0.027 & 0.033 & 0.035 & 0.029 \\
\hline & Market expansion & -0.023 & 0.526 & -0.013 & 0.810 \\
\hline & New products perception & 0.009 & 0.758 & 0.094 & 0.021 \\
\hline & No competitor perception & 0.013 & 0.738 & 0.002 & 0.958 \\
\hline & Export orientation & 0.312 & 0.000 & 0.109 & 0.217 \\
\hline & New technology & 0.008 & 0.811 & -0.060 & 0.334 \\
\hline & $\begin{array}{l}\text { New product market } \\
\text { combination }\end{array}$ & 0.034 & 0.494 & -0.093 & 0.166 \\
\hline
\end{tabular}

Dependent variables: TEA hi-growth 20+ employees and established businesses hi-growth 20+ employees

Similar to TEA entrepreneurs, informal funds in the last three years proved to be significant also for high-growth aspirations of established entrepreneurs of both genders. For male established businesses, export orientation is a predictor, slightly stronger than for their TEA counterparts, however in this case, new technologies ceased being an indicator for growth. For established women entrepreneurs, export orientation, which was significant for their TEA counterparts, is not relevant, but the perception of offering and/or producing new products for customers is an indicator of their high-growth aspirations.

The amount of variance that is explained by the independent variables in R-square shows a rather low strength of association, especially for established women entrepreneurs, with a level of only $6.2 \%$ versus their male counterparts with $11.9 \%$. 


\section{Ulrike Guelich}

The amount of variance for early-stage entrepreneurs is higher for females with a level of $14.3 \%$ than for men with $9.3 \%$.

\section{DISCUSSION}

Overall, the tendency in the six ASEAN countries is to not grow their businesses at all by employee size. A full $97.2 \%$ of both male and $98.2 \%$ of female earlystage entrepreneurs and $99.6 \%$ of male and $99.4 \%$ of female established business owners do not intend to add any additional employees within the next five years. Instead, they aim to keep their businesses as they are in terms of employee numbers. Even though high-growth entrepreneurs in both business phases only account for $2.7 \%$ of all enterprises in this study, thus confirming previous findings, or examples Davidsson et al. (2006), Minniti (2013), and Terjesen et al. (2016), we conclude, that high-growth aspirations can only partially be sustained by early-stage entrepreneurs into the next business phase. Country-level implications tend to impact entrepreneurs, especially in financial market development (highly negative) and innovation (slightly positive). Business sophistication is an important influencer of growth for established businesses of both genders. On the individual level, indicators for venture growth are: (1) having received funding for both genders; (2) being export-oriented for male entrepreneurs; and (3) perception of having new products or services to offer to the market for female entrepreneurs.

Both genders are less prone to pursue their initial early-stage growth goals as established entrepreneurs. We infer that established entrepreneurs have gained more clarity on the deployment of growth through practice in the organisation over the time of running their business and may be more realistic in their predictions or less confident to pursue high goals. All four country-level indicators of financial market development, innovation, and business sophistication and global innovativeness significantly predict high-growth aspirations of established businesses of both genders. The ASEAN region is assessed as being slightly above world average in financial market development with a score of 4.55 on a scale from 1 (largely non-existent) to 7 (extremely numerous). However, the availability of financial resources, equity, and debt for new and growing firms, including grants and subsidies is rated below average in ASEAN, with a tendency to decrease rather than to increase (Xavier et al., 2016). On the one hand, reliance on informal funding increased ASEAN entrepreneurs' aspirations to grow their ventures, whereas on the other hand, GCI Financial Market Development had a significantly and highly impactful negative influence on the growth aspirations of established entrepreneurs, confirming Banerjee and Munshi (2004), that funding constraints are a barrier to investment in high-growth and high-return activities for established entrepreneurs. 
Amongst other factors, financial market development covers the availability and affordability of financial resources, financing through the local equity market or venture capital, and ease of access to loans. As the majority of ASEAN enterprises are micro and small businesses, the negative impact of financial market development on high-growth aspirations of established entrepreneurs confirms the finding of Schiffer and Weder (2001) that lack of funding as a constraint on growth is mentioned more often by smaller rather than by larger firms. These small and medium-sized entrepreneurs in developing countries are also less likely to apply for formal bank loans, and thus typically rely on funding from family, friends and informal channels (Bigsten et al., 2003) which is supported by our findings that informal funding in the last three years significantly predicted high-growth orientation of all entrepreneurs in this study. Our finding that access to finance is significant for venture growth calls for action, as current policies in ASEAN tend to decrease the availability of funding resources for entrepreneurs.

On the other hand, business sophistication, which includes, for example, local supplier quality and quantity, value chains, production process sophistication, and extent of marketing, is a positive predictor for high-growth aspirations of established business owners. Supply and value chains are more likely to be densely prevalent for established businesses rather than for start-ups.

For start-ups and young businesses, innovation is the only predictor for highgrowth aspirations. GCI innovation covers R\&D spending, collaboration in R\&D by businesses and/or universities, capacity for innovation and government procurement of advanced tech products. On average, start-up entrepreneurs are younger in age than established entrepreneurs and tend to be more open to new technology use, which is underlined by our finding that new technology predicts high-growth aspirations of male start-ups.

However, the six surveyed countries show significant differences between each other, with Singapore being the only innovation-driven country, Malaysia in transition between efficiency- and innovation-driven, Indonesia and Thailand being efficiency-driven, and the Philippines and Vietnam being in transition between factor- and efficiency-driven. Equally, financial market development differs according to country, ranking Singapore in the top ten countries and Vietnam in the last $30 \%$ of the 140 countries in the GCI (Schwab et al., 2016). 


\section{CONCLUSION}

Some first implications for the ASEAN region, with its millions of micro enterprises and its very few high-growth businesses, result from this empirical study. The relevance of country-level indicators-which are part of the entrepreneurial ecosystem-is important since financial market development negatively influenced high-growth aspirations, especially those of established entrepreneurs. The region's economies are ranked average in the development of their financial markets, yet finance is considered to be a necessary resource for growth, implying that access to finance is an important predictor for established businesses, higher for females than for males. However, even if a supportive ecosystem is in place, high-growth entrepreneurs tend to be triggered by additional different and varying factors, confirming findings of Delmar et al. (2003).

The fact that the ASEAN Strategic Action Plan for Small and Medium-sized Enterprise Development 2016-2025 — with its aim to achieve globally competitive and innovative SMEs by promoting productivity, technology and innovation (ASEAN, 2015) - targets certain indicators, such as better access to finance and markets, internationalisation of businesses, enhanced policies and regulatory environment, may increase the probability of more high-growth firms in the region for future years.

Despite only a low number of entrepreneurs being export-oriented, this indicator proves to be one of the few highly significant ones for all early-stage entrepreneurs and also male established business owners. In addition, having received informal funding in the last three years correlates to high-growth aspirations - even if rather weak-for entrepreneurs of both genders in all business phases. The findings suggest that high-growth intentions of established entrepreneurs are less related to the strategic orientation of their respective businesses. Looking towards market expansion and export orientation, technology, and new products and services, women in ASEAN tend to be more innovative than men (Shukla et al., 2015). However, this does not lead to growth intentions for established businesses and differs from positive influencers in the early stage of their businesses. Established women entrepreneurs may be more experienced, but they may also be constrained by personal factors, including having to combine work and family. Aspirations may also have given way to a more realistic perspective: when reality pervades businesses, initial dreams and aspirations may alter. Similar to findings about intentions to start up a business, some "wishful thinking" may be involved in the high-growth aspirations of start-ups and young businesses that may not be sustainable once businesses develop further. 
To determine the necessary conditions for high-growth enterprises, previous policies give us an indication of what worked in specific contexts, while research informs us about specific types of entrepreneurship. For government policies, an institutional design approach is needed in order to affect the context of entrepreneurship (Stam $\&$ Bart, 2011). The overall effect of entrepreneurship policies changing to policies for an entrepreneurial economy (Thurik et al., 2013) will be manifested in higher levels of high-growth entrepreneurship and female entrepreneurship. As Thailand and Vietnam rank lowest in the GCI innovation pillar in this country comparison, government policies in these countries need to address improving the overall capacity for innovation as well as R\&D transfer between businesses, universities and start-ups. Malaysia and Singapore, countries that are leading this field in the region, will need more targeted government policies to increase their excellence in these areas. To support growth aspirations of established entrepreneurs, access to funding is the main constraining factor, especially in Vietnam. Government policies here - as for Indonesia, the Philippines, and Thailand - should identify long-term solutions so as to ease access to loans, venture capital, and the local equity market, while keeping an eye on the size of businesses and the aspirations of their owners to grow by 20 or more employees in the next five years. To further enhance growth of established businesses, policies should focus on strengthening the pillar of business sophistication, especially the quantity and quality of local suppliers and the depth of the value chain. The creation of the AEC and the extended single market base will most definitely strengthen businesses in the longterm and enable higher growth.

\section{Limitations and Future Research}

Like any research, this empirical study has limitations, since we view growth orientation according to employee growth measures. Different orientations such as growth of market share or revenue growth can be explained by different determinants (Delmar et al., 2003; Shepherd \& Wiklund, 2009). Future studies on growth aspirations could therefore include other variables or measures, to contrast with our results. In addition, our findings only partly explain the variance; other factors may contribute more to explaining what leads to high-growth aspirations. The ASEAN scope of this study could help to develop a clearer regional picture on entrepreneurship in a culturally diverse and rapidly developing region which is home to many micro-sized and also informal businesses (Chen, 2001) with only a tiny portion of high-growth entrepreneurs. However, because of their important contribution to economic growth (Davidsson et al., 2006; Minniti, 2013; Terjesen et al., 2016; Wong et al., 2005), we need to further research how to increase their numbers and identify the specific factors that really have impact on more 
entrepreneurs aspiring to "dream big", especially in the ASEAN region with its dynamic economic growth and positive external factors.

This study aims to contribute to the research on ambitious entrepreneurship with growth as an important factor of entrepreneurial strategy. It highlights the necessity for further research on indicators driving sustainable high-growth intentions in the established business phase of both male and female entrepreneurs who are $30 \%$ less likely to have high-growth expectations compared to early-stage entrepreneurs, even though previous findings show that established entrepreneurs in particular tend to be high-growth firms rather than start-ups. Future research needs to delve more deeply into how institutions affect the characteristics of entrepreneurial ecosystems for the promotion of high-growth entrepreneurship. However, this "global knowledge" needs to be combined with local or regional knowledge on how policy makers change institutions and how this is perceived by different types of entrepreneurs in different cultural settings and in different business phases. Researchers and public administration should not only engage with policy makers but also with entrepreneurs, to understand the key problems they are experiencing and to inform their own design of future research that is relevant to realising innovative, sustainable, and inclusive growth.

\section{REFERENCES}

ASEAN. (2015). ASEAN strategic action plan for SME development 2016-2025. ASEAN. org. https://asean.org/wp-content/uploads/2015/12/SAP-SMED-Final.pdf.

Banerjee, A., \& Munshi, K. (2004). How efficiently is capital allocated? Evidence from the knitted garment industry in Tirupur. The Review of Economic Studies, 71(1), 19-42. https://doi.org/10.1111/0034-6527.00274

Bigsten, A., Collier, P., Dercon, S., Fafchamps, M., Gauthier, B, Gunning, J.W., \& Söderbom, M. (2003). Credit constraints in manufacturing enterprises in Africa. Journal of African Economies, 12(1), 104-125. https://doi.org/10.1093/ jae/12.1.104

Brush, C., Carter, N., Gatewood, E., Greene, P., \& Hart, M. (2004). Clearing the hurdles: Women building high-growth businesses. FT Press.

Capelleras, J-L., Contín-Pilart, I., Larraza-Kintana, M., \& Martin-Sanchez, V. (2016). Unemployment and growth aspirations: The moderating role of education. Strategic Change, 25(2), 171-185. https://doi.org/10.1002/jsc.2054

Chen, M.A. (2001). Women and informality: A global picture, the global movement. Sais Review, 21(1), 71-82. https://doi.org/10.1353/sais.2001.0007

Davidsson, P., Delmar, F., \& Wiklund, J. (2006). Entrepreneurship as growth; growth as entrepreneurship. Entrepreneurship and the Growth of Firms, 1, 21-38. https:// doi.org/10.4337/9781781009949 
Delmar, F., Davidsson, P., \& Gartner, W.B. (2003). Arriving at the high-growth firm. Journal of Business Venturing, 18(2), 189-216. https://doi.org/10.1016/s0883 -9026(02)00080-0

Douglas, E.J. (2013). Reconstructing entrepreneurial intentions to identify predisposition for growth. Journal of Business Venturing, 28(5), 633-651. https://doi .org/10.1016/j.jbusvent.2012.07.005

Dumas, C. (2001). Evaluating the outcomes of microenterprise training for low income women: A case study. Journal of Developmental Entrepreneurship, 6(2), 97-128.

Dutta, S., Lanvin, B., \& Wunsch-Vincent, S. (2017). The global innovation index 2017 Innovation feeding the world (10th ed.). Cornell University, INSEAD and WIPO.

Geroski, P.A. (2002). The growth of firms in theory and in practice. Centre for Economic Policy Research (CEPR) discussion paper, UK.

Haltiwanger, J., Jarmin, R.S., \& Miranda, J. (2013). Who creates jobs? Small versus large versus young. Review of Economics and Statistics, 95(2), 347-361. https://doi .org/10.1162/rest_a_00288

Hausmann, R., Hwang, J., \& Rodrik, D. (2007). What you export matters. Journal of Economic Growth, 12(1), 1-25. https://doi.org/10.1007/s10887-006-9009-4

Henderson, J. (2002). Building the rural economy with high-growth entrepreneurs. Economic Review-Federal Reserve Bank of Kansas City, 87(3), 45-70.

Isenberg, D.J. (2010). How to start an entrepreneurial revolution. Harvard Business Review, 88(6), 40-50.

Kelley, D.J., Brush, C.G., Greene, P.G., Herrington, M., Ali, A., \& Kew, P. (2015). The global entrepreneurship monitor special report: Women's entrepreneurship 2014. The Global Entrepreneurship Research Association (GERA).

Mason, C., \& Brown, R. (2013). Creating good public policy to support high-growth firms. Small Business Economics, 40(2), 211-225. https://doi.org/10.1007/s11187-011 -9369-9

Mason, Colin, \& Brown, Ross. (2014). Entrepreneurial ecosystems and growth-oriented entrepreneurship. Final report to OECD, Paris, 30(1), 77-102.

Mead, D.C, \& Liedholm, C. (1998). The dynamics of micro and small enterprises in developing countries. World Development, 26(1), 61-74. https://doi.org/10.1016/ s0305-750x(97)10010-9

Minniti, M. (2013). The dynamics of entrepreneurship: Evidence from global entrepreneurship monitor data. Oxford University Press.

Nichter, S., \& Goldmark, L. (2009). Small firm growth in developing countries. World Development, 37(9), 1453-1464. https://doi.org/10.1016/j.worlddev.2009.01.013

Penrose, E.T. (2009). The theory of the growth of the firm. Oxford university press.

Robb, A., Coleman, S., \& Stangler, D. (2014). Sources of economic hope: Women's entrepreneurship. SSRN Electronic Journal, SSRN 2529094. https://doi .org/10.2139/ssrn.2529094

Robinson, S. (2001). An examination of entrepreneurial motives and their influence on the way rural women small business owners manage their employees. Journal of Developmental Entrepreneurship, 6(2), 151-167.

Robson, P.J.A., \& Obeng, B.A. (2008). The barriers to growth in Ghana. Small Business Economics, 30(4), 385-403. 
Schiffer, M., \& Weder, B. (2001). Firm size and the business environment: Worldwide survey results (vol. 43). World Bank Publications. https://doi.org/10.1596/978 $-0-8213-5003-4$

Schwab, K., Sala-i-Martin, X., Samans, R., \& Blanke, J. (2016). The global competitiveness report 2015/2016. http://reports.weforum.org/globalcompetitiveness-report-2015-2016/.

Shepherd, D., \& Wiklund, J. (2009). Are we comparing apples with apples or apples with oranges? Appropriateness of knowledge accumulation across growth studies. Entrepreneurship Theory and Practice, 33(1), 105-123. https://doi.org/10.1111/ j.1540-6520.2008.00282.x

Shukla, M., Guelich, U., \& Arntzen, A.A.B. (2015). An empirical investigation of gender impact on technological innovativeness among Thai entrepreneurs via GEM database. International Journal of Management Science \& Technology Information, 16, 1-15.

Stam, E., \& Bart, N. 2011. Entrepreneurship, innovation and institutions. In D.B. Audretsch, O. Falck, \& S. Heblich, Handbook of research on innovation and entrepreneurship (pp. 421-38). Edward Elgar. https://doi.org/10.4337/9781849807760

Swinnen, J.F. (2005). When the market comes to you-or not: The dynamics of vertical co-ordination in agro-food chains in Europe and Central Asia. The World Bank.

Terjesen, S., Bosma, N., \& Stam, E. (2016). Advancing public policy for high-growth, female, and social entrepreneurs. Public Administration Review, 76(2), 230-239. https://doi.org/10.1111/puar.12472

Thurik, R., Stam, E., \& Audretsch, D. (2013). The rise of the entrepreneurial economy and the future of dynamic capitalism. Technovation, 33(8-9), 302-310. https://doi .org/10.1016/j.technovation.2013.07.003

Wong, P.K., Ho, Y.P., \& Autio, E. (2005). Entrepreneurship, innovation and economic growth: Evidence from GEM data. Small Business Economics, 24(3), 335-350. https://doi.org/10.1007/s11187-005-2000-1

World Bank. (2014). The female entrepreneurship resource point. World Bank.

Xavier, S. R., Guelich, U., Kew, P., Nawangpalupi, C., \& Velasco, A. (2015). ASEAN regional entrepreneurship report 2014/15. Driving ASEAN entrepreneurship: Policy opportunities for inclusiveness and sustainable entrepreneurial growth. London: GERA. https://gemconsortium.org/report/49173. https://doi .org/10.4337/9781785364624.00007

Xavier, S.R., Sidin, S.M., Guelich, U., \& Nawangpalupi, C. (2016). ASEAN entrepreneurship: The context, impact and opportunities for women entrepreneurs and startups; key pivots for growth and sustainability. Kuala Lumpur: University Tun Abdul Razak. https://gemconsortium.org/report/49766. 